\title{
POLIGAMI TANPA IZIN ISTERI DALAM PERSPEKTIF HUKUM: BENTUK KEKERASAN PSIKIS TERHADAP ISTERI
}

Halaman | 26

\author{
Rizkal
}

Fakultas Syariah dan Ekonomi Islam, Universitas Iskandarmuda Banda Aceh

Email : Rizkalhusaini91@gmail.com

\begin{abstract}
In general, the Law of Marriage in Indonesia adheres to the principle of monogamy, although it does not rule out the possibility for husbands to have wife of more than one person at a time, or known as polygamy. The polygamy marriage desired in Article No. 1 of 1974 concerning Marriage and in the Compilation of Islamic Law is conditional polygamy, where the husband is permitted to marry polygamy with the provisions that must meet the juridical requirements stated in the Marriage Law and KHI. One of the requirements is that there is an agreement or permission from the first wife made in writing. Polygamy without the permission of the first wife will cause conflict in the household, namely psychological violence conflict suffered by the wife. So that the wife will ask for divorce because she feels betrayed by her husband. In such circumstances, the wife will feel very aggrieved by the act of polygamy secretly, the psychological disturbance due to betrayal by the husband, and other disadvantages are the wife is not entitled to a mut'ah post-divorce from the husband, because this divorce was submitted at will the wife herself.
\end{abstract}

Keywords: Polygamy, Wife Permit, Psychic violence.

\section{Pendahuluan}

Perkawinan merupakan suatu ikatan sosial atau suatu ikatan perjanjian hukum antara pribadi manusia dalam membentuk hubungan kekerabatan atau membentuk sebuah keluarga. Dasar hukum pelaksanaan perkawinan di Indonesia telah diatur dalam ketentuan Undangundang Nomor 1 Tahun 1974 tentang Perkawinan (Selanjutnya disebut UU Perkaiwan) dan juga diatur dalam Instruksi Presiden (Inpres) Nomor 1 Tahun 1991 tentang Pelaksanaan Kompilasi Hukum Islam (selanjutnya disebut dengan KHI). Dalam ketentuan Pasal 1 UU Nomor 1 Tahun 1974 Tentang Perkawinan, mendefinisikan perkawinan sebagai sebuah ikatan lahir batin antara seorang pria dengan seorang wanita sebagai suami isteri dengan tujuan membentuk keluarga (rumah tangga) yang bahagia dan kekal berdasarkan Ketuhanan yang maha Esa. Sementara itu, Pasal 2 Buku I Hukum Perkawinan KHI mendefinisikan perkawinan yaitu akad yang sangat kuat atau mitsaqan ghalizan untuk mentaati perintah Allah dan melaksanakannya merupakan ibadah.

Konsep hukum perkawinan di Indonesia pada dasarnya menganut asas monogami, yaitu seorang pria hanya boleh mempunyai seorang isteri dalam satu waktu tertentu begitu juga bagi perempuan. Asas monogami dalam perkawinan bersifat terbuka (tidak mutlak), artinya bahwa seorang suami dapat mempunyai lebih dari seorang isteri, hal ini dapat dilakukan apabila dikehendaki dan sesuai dengan hukum agama si suami. (Dahlan Hasyim, 2007).

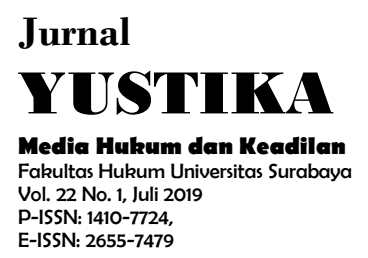

Jurnal 
Jurnal Yustika

Vol. 22 No. 1, Juli 2019

Halaman | 27

POLIGAMI TANPA IZIN ISTERI DALAM

PERSPEKTIF HUKUM: BENTUK KEKERASAN PSIKIS TERHADAP ISTERI Rizkal

Asas monogami bersifat terbuka (tidak mutlak) sebagaimana disebutkan di atas, dapat dilihat pada ketentuan Pasal 2 ayat (2), Pasal 4, dan Pasal 5 ayat (1)UU Perkawinan. Selain itu, juga diatur dalam Pasal 55, Pasal 56 ayat (1), dan Pasal 57 KHI. Bahkan dalam ketentuan hukum Islam juga diatur dalam al-Qur'an, yaitu dalam surah An-Nissa ayat 3 yang artinya: "dan jika kamu takut tidak akan berlaku adil terhadap hak-hak perempuan bila kamu menikahinya, maka nikahila wanita-wanita lain yang kamu senangi dua, tiga atau empat. Kemudian jika kamu takut tidak berlaku adil maka kawinilah seorang saja.

Meskipun Undang-undang Perkawinan menganut asas monogami sebagaimana yang disebutkan dalam ketentuan pasal-pasal di atas. Namun dalam ketentuan Pasal 3 ayat (2) UU Perkawinan menyebutkan tentang memberikan kesempatan bagi laki-laki (suami) untuk beristri lebih dari satu orang dalam satu waktu apabila dikehendaki oleh pihak-pihak yang bersangkutan. Prosedur seorang suami untuk beristeri lebih dari satu orang telah diatur dengan jelas dalam ketentuan Pasal 4 dan Pasal 5 UU Perkawinan serta juga diatur dalam ketentuan Pasal 55 dan Pasal 56 KHI.

Praktik perkawinan poligami banyak menuai pro dan kontra di kalangan masyarakat. Mereka yang mendukung poligami biasanya beralasan karena Islam membolehkan suami menikahi perempuan sampai 4 orang dalam satu waktu, sedangkan mereka yang tidak mendukung atau menentang poligami antara lain sebagai berikut: (Ustad Labib MZ: 1986).

a) Poligami kerap merendahkan derajat kaum wanita

b) Poligami menyebabkan merajalelanya perzinaan

c) Poligami menyebabkan kacau balaunya rumah tangga, sebab biasanya cinta sang suami akhirnya hanya tertuju kepada isteri yang baru.

Sejatinya praktik perkawinan poligami pada dasarnya bertujuan untuk membuat derajat kaum wanita lebih baik, tujuan ini yang diterapkan oleh Nabi Muhammad pada saat melakukan perkawinan poligami, dengan syarat mampu berlaku adil baik secara lahir maupun bathin. Namun pada dewasa ini, praktik poligami kerap disalah artikan oleh sebagian orang, di mana konsep poligami yang berkembang suami dapat menikahkan perempuan sampai dengan empat orang dalam satu waktu tanpa memperhatikan syarat- syarat yang telah ditentukan baik yang disebutkan dalam ketentuan al-Quran maupun dalam ketentuan peraturan perundangundangan tentang perkawinan di Indonesia.

Ketidakpeduliannya seorang suami yang hendak berpoligami terhadap syarat- syarat poligami yang mengharuskan adanya izin isteri secara tertulis, mengakibatkan poligami akan dilakukan secara sirri, yakni perkawinan poligami tersebut dilakukan di bawah tangan tanpa adanya akta nikah yang resmi dikeluarkan oleh Kantor Urusan Agama (KUA). Di samping itu, perkawinan poligami tersebut juga akan menimbulkan konflik baru dalam keluarga antara suami dengan isteri pertama. Konflik ini akan berkelanjutan sampai isteri bisa menerima wanita (isteri kedua suami) masuk dalam hidup rumah tangganya, isteri bersedia membagi kasih sayang suaminya dengan wanita lain, dan yang paling penting isteri sanggup menerima dan memaafkan penghianatan perkawinan yang dilakukan oleh suami terhadap dirinya.

Konflik yang muncul pasca suami berpoligami tanpa izin isteri pertama berujung dengan pengajuan cerai ke Pengadilan Agama (Mahkamah Syar'iyyah) dengan alasan isteri merasa dikhianati oleh sang suami yang telah menikah dengan wanita lain secara diam- diam. 
Kasus semacam ini pernah terjadi di Pengadilan Agama Jakarta Timur dengan Putusan Nomor: 0478/Pdt.G/2017/PAJT, adapun yang menjadi alasan isteri mengajukan gugatan cerai ke Pengadilan Agama Jakarta Timur dikarenakan sang suami (tergugat) telah menikah lagi dengan perempuan lain tanpa seizin isteri (penggugat) dan izin dari Pengadila Agama, dan hal tersebut telah melanggar ketentuan Pasal 56 ayat (1), Pasal 58 ayat (1) huruf (a), Pasal 116 huruf (g) Kompilasi Hukum Islam.

Perkawinan poligami yang dilakukan oleh suami tanpa adanya isteri pertama menimbulkan banyak kerugian bagi isteri. Kerugikan yang dialami isteri yaitu kerugian secara lahir dan bathin atas pengkhinatan yang dilakukan oleh sang suami atas perkawinan yang telah dibangun. Selain itu, isteri juga merasa dirugikan ketika mengajukan cerai ke Pangadilan, di mana isteri tidak berhak menerima nafkah mut'ah dari suami, hal ini disebabkan permintaan cerai ke Pengadilan Agama diajukan atas kemauan isteri sendiri, berdasarkan ketentuan Pasal 158 KHI yaitu: Mut'ah wajib diberikan oleh sang suami kepada isteri dengan syarat; (a) belum ditetapkannya mahar bagi isteri ba' da dukhul, dan (b) perceraian itu atas kehendak suami.

Berdasarkan uraian yang telah dijabarkan di atas, maka yang menjadi pokok persoalannya adalah perkawinan poligami yang dilakukan tanpa adanya izin isteri pertama menimbulkan banyak kerugian bagi isteri, baik kerugian secara lahir maupun bathin, yaitu isteri merasa tertekan psikisnya dengan mengetahui suami telah berbuat curang terhadapnya dan berujung pada pengajuan gugatan cerai ke Pengadilan Agama. Di mana seharusnya sesuai dengan ketentuan UU Perkawinan dan Kompilasi Hukum Islam suami berkewajiban memintai izin isteri pertama sebagai salah satu syarat yang harus dipenuhi apabila ia akan menikah untuk kedua kalinya. Namun pada praktiknya, masih kurangnya kesadaran hukum bagi suami dalam mengartikan konsep poligami sebagaimana diamanatkan dalam UU Perkawinan. Praktik poligami yang dijalankan hanya melihat dari sisi agama saja, selama rukun dan syarat perkawinan telah terpenuhi maka perkawinan tersebut dianggap sah secara agama., namun mengesampingkan ketentuan hukum negara. Pada dasarnya, perkawinan poligami baik yang kedua, ketiga dan keempat yang dilakukan oleh suami tidak bisa disamakan dengan kondisi perkawinan pertamanya, hal ini dikarekan adanya syarat tambahan utama yang harus dipenuhi oleh suami ketika hendak berpoligami, yakni terpenuhinya syarat izin isteri dan izin pengadilan.

\section{Pembahasan}

\subsection{Poligami Dalam Hukum Islam dan Hukum Positif Indonesia}

Kehadiran lembaga poligami versi Islam sesungguhnya telah merupakan reformasi sosial- kultural dari apa yang pernah ada di era pra Islam (tradisi jahiliyah). Kaum perempuan tak ubah pakaian yang bisa dimiliki sebanyak- banyaknya tanpa batas moral dan etika, lalu dilepas begitu saja jika sudah tak lagi berselera. Kaum perempuan yang yang sebelumnya diperlakukan tidak secara manusiawi sedemikian itu, lewat Syariat Islam yang luhur, lalu diangkat derajat mereka menjadi manusia seutuhnya. Hak- hak kaum perempuan diberikan sesuai kodrat dan peranannya secara fitrah, termasuk dalam hal perkawinan. Maka lewat syariat yang sempurna, Islam hadir salah satunya dengan mengusung semangat mengangkat harkat dan martabat kaum perempuan agar sampai pada porsi mereka sebagai manusia 
Jurnal Yustika

Vol. 22 No. 1, Juli 2019

Halaman I 29

POLIGAMI TANPA IZIN ISTERI DALAM PERSPEKTIF HUKUM: BENTUK KEKERASAN PSIKIS TERHADAP ISTERI Rizkal seutuhnya. Mengikis perlakuan diskriminatif yang selama ini memasang kaum perempuan (Erfani Aljan Abdullah, 2017).

Pada dasarnya, Islam membolehkan poligami dengan jumlah wanita yang terbatas dan tidak mengharuskan umatnya melaksanakan monogami mutlak. Islam tidak menutup kemungkinan adanya laki-laki berpoligami, tetapi tidak semua laki-laki harus berbuat demikian karena tidak semuanya mempunyai kemampuan untuk berpoligami. Poligami dalam Islam dibatasi dengan syarat-syarat tertentu, baik jumlah maksimal maupun persyaratan lannya, yaitu:

a. Jumlah isteri yang boleh dipoligami paling banyak emoat orang wanita. Seandainya salah satu di antaranya ada yang meninggal atau diceraikan, maka suami dapat mencari ganti yang lain asalkan jumlahnya tidak melebihi empat orang wanita dalam waktu yang bersamaan. Hal ini sesuai dengan Firmah Allah dalam Surah An- Nissa ayat 3.

b. Laki- laki dapat berlaku adil terhadap isteri- isteri dan anak- anaknya, yang menyangkut masalah- masalah lahiriyah seperti pembagian waktu dan pembagian nafkah. Sedangkan masalah bathin, tentu saja selamanya manusia tidak mungkin dapat berbuat adil secara hakiki.

Para ulama sepakat bahwa keadilan merupakan syarat mutlak dan tidak dinegosiasikan dalam poligami. Syarat adil dalam poligami menjadi konsekuensi yang penting. Karena adil itu adalah suatu tugas keagamaan yang wajib dilaksanakan oleh setiap manusia,sama saja orang- orangnya berpoligami atau bermonogami. Dalam hal ini, Dr. Abdul Nasir Taufik al- 'Athar memberikan standar keadilan dalam poligami. Menurutnya, Allah sudah menurunkan ayat yang mengandung prinsip keadilan yaitu "kalau kamu khawatir akan tidak berlaku adil, maka hendaklah kamu menikah dengan seorang saja". Sebenarnya ini saja keterangannya di dalam Al- Quran sudah cukup. Tetapi demi kepentingan masalah keadilan dalam poligami, Al- Quran juga memuat fatwa yang berhubungan dengan jelas tentang standar keadilannya yang dituntut dalam ayat- ayat itu, dan diberi ketentuannya dengan dua perkara, yaitu: (Sulaiman Al- Kumayi: 2007).

a) Yang dinilai adalah niat yang baik dan amal yang shalih. Allah berfirman: "Kebajikan apa saja yang kamu kerjakan, Allah tentu mengetahuinya". Inilah standar keadian pertama yang dijelaskan dalam surah An- Nissa ayat 3. Jadi, niat yang baik, yang dilaksanakan dengan maksud yang baik dan dibarengi dengan perbuatan yang baik.

b) Menurut asalnya, keadilan itu adalah persamaan antara dua yang bersamaan. Misalnya bahwa setiap isteri sama dengan isteri yang lain, dalam nilainya sebagai isteri; karena yang menjadi ukuran adalah hubungan sebagai suami isteri. Maka keadilan itu menghendaki persamaan antara suami- isteri itu, dalam makanan, pakaian, nafkah, tempat tinggal, hubungan dengan suaminya, kasih dan sayangnya, daln lain- lain, sehingga sebagian dari ulama- ulama memperhitugkan juga dengan hubunganhubungan yang kecil- kecil. Sehingga setiap isteri jangan sampai mendapat lebih banyak dari isteri yang lain.

Ketentuan hukum Perkawinan di Indonesia, kemudian mengadopsi lembaga poligami tersebut sebagai bagian dari ketentuan perkawinan yang diakui namun dengan memberikan beberapa ketentuan syarat pengetatan. Adanya syarat-syarat poligami yang diatur dalam 
Undang-Undang Perkawinan, pada dasarnya berangkat dari kemelut dan tarik ulur ideologi antara pergerakan kaum perempuan di Indonesia yang menentang poligami, dan Partai Persatuan Pembangunan (PPP) sebagai representasi umat Islam di DPR yang mendukung adanya pasal poligami dalam Undang-Undang Perkawinan (Wila Chandrawila Supriadi, 2002). Pergulatan itu kemudian berujung pada disahkannya Undang-Undang Nomor 1 Tahun 1974 tentang Perkawinan pada tanggal 2 Januari 1974, di mana dalam UU tersebut tetap diatur tentang poligami dengan alasan dan persayaratan tertentu.

Seorang suami yang hendak menikah lebih dari seorang, harus mendapat izin dari Pengadilan Agama. Suami tersebut dapat mengajukan perkara permohonan izin poligami ke Pangadilan Agama di wilayah tempat tinggalnya dan isterinya, secara kontentius dengan menundukkan isteri pertama sebagai termohon. Dan jika Majelis Hakim Pengadilan Agama berpendapat permohonan tersebut terbukti beralasan secara hukum dan telah memenuhi persyaratan sebagaimana dimaksu dalam undang-undang perkawinan, maka permohonan tersebut dapat dikabulkan yang selanjutnya akan dituangkan dalam bentuk putusan (vonnis) memberi izin kepada pemohon (suami) untuk menikah lagi dengan seseorang perempuan sebagaimana yang disebutkan pemohon dalam permohonannya sebagai calon isteri keduanya ((Erfani Aljan Abdullah, 2017).

Syarat harus adanya izin isteri pertama secara tertulis di hadapan Pengadilan Agama sesuai dengan ketentuan Pasal Pasal 3 dan Pasal 5 Undang-Undang Perkawinan. Pasal 3 UU Perkawinan menyebutkan bahwa; pada azasnya dalam suatu perkawinan seorang pria hanya boleh mempunyai seorang isteri. Seorang wanita hanya boleh mempunyai seorang suami. Dan pengadilan dapat memberi izin kepada seorang suami untuk beristeri lebih dari seorang apabila dikehendaki oleh pihak-pihak yang bersangkutan. Selanjutnya dalam Pasal 5 UU Perkawinan menyebutkan beberapa syarat yang harus dipenuhi oleh sang suami apabila mengajukan permohonan poligami kepada pengadilan, diantaranya adalah sebagai berikut:

a. Adanya persetujuan dari isteri/ isteri-isteri, persetujuan ini tidak diperlukan bagi seorang suami apabila isteri/ isteri-isterinya tidak mungkin dimintai persetujuannya dan tidak dapat menjadi pihak dalam perjanjian, atau apabila tidak ada kabar dari isterinya selama sekurang-kurangnya 2 (dua) tahun, atau karena sebab-sebab lainnya yang perlu mendapat penilaian dari Hakim Pengadilan.

b. Adanya kepastian bahwa suami mampu menjamin keperluan- keperluan hidup isteri-isteri dan anak-anak mereka

c. Adanya jaminan bahwa suami akan berlaku adil terhadap isteri-isteri dan anak-anak mereka

Pada dasarnya, ketentuan bahwa Pengadilan Agama baru dapat memberikan izin poligami, jika salah satu alasan- alasan poligami dibenarkan oleh undang-undang perkawinan telah terpenuhi. Hal ini sesuai dengan ketentuan Pasal 4 ayat (2) Undang- Undang Perkawinan. Adapun alasan-alasan tersebut adalah sebagai berikut:

a. Isteri tidak dapat menjalankan kewajibannya sebagai isteri.

b. Isteri mendapat cacat badan atau penyakit yang tidak dapat disembuhkan.

c. Isteri tidak dapat melahirkan keturunan. 
Jurnal Yustika

Vol. 22 No. 1, Juli 2019

Halaman | 31

POLIGAMI TANPA

IZIN ISTERI DALAM

PERSPEKTIF HUKUM: BENTUK KEKERASAN PSIKIS TERHADAP ISTERI Rizkal

Alasan-alasan poligami tersebut sebagaimana disebutkan dalam ketentuan Pasal 4 ayat (2) UU Perkawinan tidak dijelaskan secara rinci (detail) baik adalam UU Perkawinan maupun dalam ketentuan pejelasannya. Oleh karena itu, alasan- alasan pembenar polgami tersebut membingungkan, apakah ketentuan Pasal tersebut bersifat kumulatif atau alternatif. Maka dari itu, penggunaan alasan- alasan poligami tersebut diserahkan kepada hakim yang memeriksa permohonan poligami tersebut (Abdul Manan, 2006).

Meskipun alasan-alasan pembenar bagi laki-laki (suami) untuk melakukan poliogami sebagaimana tersebut di atas sudah dipenuhi. Pengadilan Agama juga harus meneliti apakah ada atau tidaknya syarat- syarat tertentu secara kumulatif yaitu:

a. Persetujuan dari isteri atau isteri-isterinya, kalau ada harus diucapkan di muka (hadapan) majelis hakim.

b. Kemampuan secara materiil dari orang yang bermaksud menikah lebih dari satu orang, dan

c. Jaminan berlaku adil terhadap isteri- isterinya apabiola ia sudah menikah, jaminan yang berlaku adil ini dibuat dalam persidangan di hadapan majelis hakim.

Apabila syarat- syarat kumulatif ini sudah terpenuhi secara kumulatif, maka barulah Pengadilan Agama memberi izin kepada pemohon untuk melaksanakan perkawinan lebih dari satu orang isteri. Namun apabila perkawinan poligami tidak dilaksanakan sebagaimana ketentuan tersebut di atas, maka perkawinan tersebut tidak dibenarkan menurut hukum dan tidak berdasarkan hukum perkawinan di Indonesia.

\subsection{Poligami Tanpa Izin Isteri Pertama Sebagai Bentuk Kekerasan Psikis Terhadap Isteri Dalam Rumah Tangga}

Kekerasan dalam rumah tangga (KDRT) merupakan suatu bentuk pelanggaran Hak Asasi Manusia (HAM) yang harus segera diselesaikan. Siapa saja dapat menjadi korban kekerasan dalam rumah tangga, baik suami, isteri, anak-anak dan anggota keluarga lainnya yang tidak dalam rumah tangga, namun saat ini yang paling banyak menjadi korban kekerasan dalam rumah tannga adalah perempuan (isteri) dan anak. Adapun yang menjadi bentukbentuk kekerasan dalam rumah tangga antara lain sebagai berikut: (Ridwan: 2006).

a) Kekerasan fisik adalah perbuatan yang mengakibatkan rasa sakit, jatuh sakit atau luka berat. Dalam konteks relasi personal, bentuk- bentuk kekerasan fisik yang dialami perempuan mencakup antara lain: tamparab, pemukulan, penjambakan, penginjakinjakan, penendangan, pencekikan, lemparan benda keras, penyiksaan dengan menggunakan benda tajam, seperti pisau,gunting setrika serta pembakaran. Sedangkan dalam konteks relasi kemasyarakatan, kekerasan fisik terhadap perempuan bisa berupa penyekapan ataupun pemerkosaan terhadap pembantu perempuan oleh majikan ataupun pengrusakan alat kelamin yang dilakukan atas nama budaya atau kepercayaan tertentu.

b) Kekerasan seksual adalah pemaksaan hubungan seksual yang dilakukan terhadap orang yang menetap dalam rumah tangga atau pemaksaan hubungan seksual terhadap salah seorang dalam lingkup rumah tangganya dengan orang lain untuk tujuan komersil dan/ atau tujuan tertentu. Kekerasan yang bernuansa seksual termasuk 
berbagai perilaku yang tak diinginkan dan mempunyai makna seksual atau sering disebut dengan istilah pelecehan seksual, maupun berbagai bantuk pemaksaan hubungan seksual yang sering disebut dengan istilah perkosaan.

c) Kekerasan psikologis adalah perbuatan yang mengakibatkan ketakutan, hilangnya rasa percaya diri, hilangnya kemampuan untuk bertindak, rasa tidak berdaya, dan/ atau penderitaan psikis berat pada seseorang. Bentuk kekerasan secara psikologis yang dialami perempuan mencakup makian, penghinaan yang berkelanjutan untuk mengecilkan harga diri korban, bentakan dan ancaman yang dimaksudkan untuk memunculkan rasa takut. Pada umumnya kekerasa psikologis ini terjadi dalam konteks relasi personal.

d) Penelantaran rumah tangga adalah seseorang tidak melaksanakan kewajiban hukumnya terhadap orang dalam lingkup rumah tangga berupa mengabaikan memberikan kewajiban kehidupan, perawatan atau pemeliharaan kepada orang tesrebut. Termasuk dalam kategori penelantaran rumah tangga adalah memberikan batasan atau melarang seseorang bekerja yang layak di dalam atau di luar rumah sehingga korban beda dalam kendali orang tersebut.

Bentuk- bentuk kekerasan sebagaimana diatur dalam Undang-Undang PDKRT sesungguhnya merupakan cermin dari berbagai bentuk keerasan yang sering terjadi dan menjadi fenomena umum di tengah- tengah masyarakat.

Perkawinan lebih dari satu orang (poligami) yang dilakukan oleh suami merupakan suatu hal yang sangat ditakuti oleh setiap isteri (wanita). Pelaksanaan poligami tanpa dibatasi oleh peraturan perundang- undangan yang membatasinya secara ketat, akan menimbulkan halhal yang bersifat negatif dalam kehidupan berumah tangga. Karena biasanya hubungan antara isteri tua (isteri pertama) dengan isteri muda (madu isteri tua) menjadi tegang dan tidak harmonis. Sementara itu, anak- anak yang berlainan ibu juga akanm menjurus kepada pertentangan antara satu dengan lainnya yang dapat membahayakan kelangsungan hidupnya sebagai saudara seayah. Oleh karena itu, untuk menimalisir hal-hal bersifat negatif yang timbul dari perkawinan poligami dalam keluarga, maka Undang-Undang Perkawinan membatasi secara ketat pelaksanaan perkawinan poligami dengan mengantisipasi lebih awal membatasi kawin lebih dari satu orang dengan alasan- alasan dan syarat- syarat tertentu sebagaimana yang telah disebutkan dalam sub judul sebelumnya.

Salah satu syarat yang harus dipenuhi oleh suami yang akan melangsungkan perkawinan poligami dengan wanita lain adalah harus adanya bukti tertulis izin dari isteri pertama. Selain itu disyaratkan juga mendapatkan izin dari Pengadilan Agama disertai dengan alasan-alasan yang dibenarkan dalam Undang-Undang Perkawinan. Tidak sahnya perkawinan poligami yang dilakukan oleh suami tanpa adanya izin tertulis dari isteri pertama menurut ketentuan hukum perkawinan di Indonesia.

Salah satu kasus tentang isteri gugat cerai suami dengan alasan suami melakukan poligami tanpa izin isteri dapat dilihat dalam Putusan Nomor: 0478/Pdt.G/2017/PAJT. Dalam putusan tersebut disebutkan bahwasanya dasar gugatan cerai diajukan ke Pengadilan Agama dikarenakan suami telah menikahi wanita lain secara diam- diam tanpa sepengetahuan isteri pertamanya pada tahun 2009, dan perkawinan poligami tersebut baru diketahui oleh sang isteri pada tahun 2016 dan telah mempunyai 2 orang anak hasil dari perkawinan poligami tersebut. 
Jurnal Yustika

Vol. 22 No. 1, Juli 2019

Halaman | 33

POLIGAMI TANPA IZIN ISTERI DALAM PERSPEKTIF HUKUM: BENTUK KEKERASAN PSIKIS TERHADAP ISTERI Rizkal
Gugat cerai yang diajukan oleh isteri ke Pengadilan Agama merupakan hasil pemikiran dan pertimbangan panjang yang harus dilaluinya, mengetahui suami menikah dengan perempuan lain membuat rasa tertekan secara psikis bagi isteri.

Perkawinan poligami tanpa izin isteri pertama dapat menjadi sebuah problematika yang serius dalam kehidupan berumah tangga. Hal ini mengingat bahwasanya suami telah secara diam- diam mengkhianati janji suci perkawinan yang telah diakadkan pada saat menikahi isterinya. Di samping itu, kondisi bathin isteri yang tidak bisa menerima masuknya perempuan baru ke dalam kehidupan suaminya juga membuat isteri tertekan secara bathin (psikis). Maka dari itu, menurut hemat penulis, tertekannya dan merasa dikhianati isteri oleh perbuatan poligami sang suami dapat dikategorikan sebagai salah satu bentuk kekerasan dalam rumah tangga (KDRT) secara psikologis, bahkan apabila si isteri tidak sanggup bertahan dan mengakukan gugatan perceraian isteri akan mengalami kerugian lainnya, yakni tidak mendapatkan nafkah mut'ah selama proses perceraian, hal ini dikarenakan gugatan cerai tersebut atas dasar kemamuan isteri. Sementara secara yuridis pemberian nafkah mutah baru bisa diberikan kepada isteri apabila suami yang melakukan cerai kepada isterinya.

Praktik poligami tanpa izin isteri pertama yang dilakukan oleh suami terhadap isteri yang dapat menjalankan tugas dan kewajibannya sebagai isteri adalah sebuah perbuatan hukum yang salah, dan tidak sesuai dengan ketentuan poligami yang telah diatur dalam UU Perkawinan maupun dalam Kompilasi Hukum Islam (KHI). Di samping melanggr ketentuan kedua aturan hukum tersebut, perselingkuhan antara suami dengan perempuan lain yang berujung pada perkawinan poligami tanpa izin isteri pertama juga melanggar ketentuan Pasal 279 Kitab Undang- Undang Hukum Pidana, yang menyebutkan bahwa: Barang siapa mengadakan perkawinan padahal mengetahui bahwa perkawinan atau perkawinanperkawinannya yang telah ada menjadi penghalang yang sah untuk itu. Serta apabila dengan sengaja menyembunyikan kepada pihak lain bahwa perkawinan yang telah ada menjadi penghalang yang sah untuk itu diancam dengan pidana penjara paling lama tujuh tahun.

Komisioner Komisi Nasional (Komnas) Perempuan Sri Nurherawati menyebutkan bahwasanya undang-undang perkawinan di Indonesia yang mengatur masalah poligami bersifat diskriminatif terhadap perempuan dan hanya menguntungkan pihak laki-laki sebagai suami. Menurutnya, dalam UU perkawinan tersebut istri tidak mempunyai posisi seimbang dalam rumah tangga sebagaimana hak dan kewajiban suami-istri saling mencintai, dan saling menghormati dalam perkawinan. Hal itu pula, yang menyebabkan kesetaraan perempuan dalam perkawinan tidak dilindungi. Terlebih lagi ketika istri dalam kondisi sakit yang tak dapat disembuhkan yang menyebabkan tidak dapat menjalankan kewajiban sebagai seorang isteri. (Republika.co.id edisi Senin, 24 Dec 2018). Seyogyanya suami yang sudah berjanji mengikat dirinya dengan isteri melalui akad perkawinan harus menerima isterinya apa adanya. Selanjutnya, Komnas Perempuan juga mengatakan bahwasanya implementasi poligami saat ini cenderung mengarah ke dalam kategori kekerasan dalam rumah tangga yang termasuk dalam kejahatan perkawinan. Jika kekerasan dalam rumah tangga terjadi yang berujung pada permohonan perceraian dari isteri terhadap suami, maka hak-hak istri seperti nafkah dan hak waris terbengkalai dan melenceng dari perlindungan hukum bagi isteri itu sendiri.

Berdasarkan uraian di atas, maka dapat dikatakan bahwasanya posisi isteri selalu menjadi korban dari perbuatan suami yang melakukan poligami secara diam- diam. Di 
samping itu, isteri banyak mengalami kerugian yang ditimbulkan dari perbuatan poligami suami, yaitu:

Jurnal Yustika Vol. 22 No. 1, Juli 2019

a) Kerugian secara bathin, artinya isteri menjadi korban penipuan sang suami yang telah mengkhianati pernikahnnya dengan menikahkan wanita lain secara diamdiam tanpa sepengetahuannya. Dalam kondisi seperti ini kejiwaan sang isteri akan terganggu dan membuat ketidakstabilan psikis isteri. Kerugian secara bathin ini dapat dikategorikan sebagai sakah satu bentuk kekerasan secara psikis yang dilakukan oleh suami kepada isteri.

b) Kerugian secara materiil, artinya isteri yang menjadi korban pengkhinatan suami yang melakukan poligami secara diam- diam, sangat sulit bisa menerima keadaan yang terjadi seolah-olah tidak terjadi apa-apa dalam hidup rumah tangganya, sehingga akan menimbulakan konflik berkelanjutan dalam rumah tangga yang berujung pada diajukannya gugatan cerai oleh sang isteri ke Pengadilan Agama. Dalam hal ini, ketika isteri mengajukan gugatan cerai terhada suami di Pengadilan Agama, maka secara hukum isteri tidak berhak menerima nafkah mut'ah dari sang suami, hal ini dikarenakan putusnya perkawinan antara suami dan isteri didasarkan pada kemauan sang isteri itu sendiri, sehingga isteri tidak berhak menerima nafkah mut'ah dari suaminya.

Kerugian- kerugian yang dialami oleh isteri sebagaimana tersebut di atas, dapat diminimalisirkan dengan ditingkatkannya pemahanan hukum dan kesadaran hukum bagi para suami yang akan melakukan perkawinan poligami, dan juga peningkatan pemahaman dan kesadaran hukum bagi para pelaku pernikahan poligami untuk selalu mengedepankan ketentuan yuridis dalam hal perkawinan poligami. Suami wajib memperhatikan ketentuan poligami dengan seksama, baik konsep poligami menurut Islam maupun juga menurut peraturan perundang-undangan tentang perkawinan.

\section{Kesimpulan}

Peraturan Perundang- undangan Nomor 1 Tahun 1974 tentang Perkawinan dan Kompilasi Hukum Islam tidak melarang suami untuk memiliki isteri lebih dari satu orang dalam waktu, hal ini sesuai dengan konsep poligami dalam Islam, di mana suami dibenarkan memiliki isteri lebih dari satu dalam satu waktu dengan syarat suami mampu berlaku adil terhadap isteri- isterinya. Sementara itu, dalam UU Perkawinan dn KHI membolehkan suami untuk melakukan poligami dengan syarat isteri tidak bisa menjalankan tugas dan kewajibannya sebagai isteri, maka isteri dapat memberikan izin secara tertulis kepada suami untuk menikahi perempuan lain, ketentuan ini dapat dilihat dalam Pasal 55 sampai Pasal 59 Kompilasi Hukum Islam, seerta dapat dilihat juga dalam ketentuan Pasal 3 sampai Pasal 5 UU Perkawinan.

Praktik poligami yang dialkukan oleh suami tanpa adanya izin dari isteri pertama merupakan sebuah kobohongan dan pengkhinatan suami terhadap isteri, dan dapat dikategorikan sebagai bentuk kekerasan rumah tangga dalam konteks kekerasan secara psikis. Di mana isteri yang mengetahui suaminya telah menikah dengan perempuan lain tanpa sepengetahuannya sedangkan isteri masih mampu melaksanakan tugas dan kewajibannya sebagai isteri akan merasa sakit hatinya dan bahkan terganggu bathinnya. Di samping itu juga
Halaman | 34

POLIGAMI TANPA IZIN ISTERI DALAM PERSPEKTIF HUKUM: BENTUK KEKERASAN PSIKIS TERHADAP ISTERI Rizkall 
Jurnal Yustika

Vol. 22 No. 1, Juli 2019

Halaman I 35

POLIGAMI TANPA IZIN ISTERI DALAM PERSPEKTIF HUKUM: BENTUK KEKERASAN PSIKIS TERHADAP ISTERI

banyak kerugian yang dialami oleh sang isteri pertama dari perbuatan poligami yang dilakukan oleh sang suami, baik kerugian karena merasa suaminya telah dirampas dan harus berbagi cinta dan kasih sayang dengan wanita lain padahal perkawinannya dengan suami masih dalam keadaan baik- baik saja sebelum terbongkarnya perselingkuhan sang suami. Selain itu, juga kerugian tidak dapat diberikannya nafkah mut'ah dari suami kepada isteri, hal ini terjadi apabila isteri yang tidak tahan lagi hidup dengan suaminya mengajukan gugatan cerai ke Pengadilan Agama. Kasus seperti ini pernah terjadi dan telah diselesaikan serta diputuskan oleh Majelis Hakim Pengadilan Agama Jakarta Timur dengan Putusan Nomor: 0478/Pdt.G/2017/PAJT.

\section{Rizkal}




\section{Daftar Referensi}

Buku:

Jurnal Yustika Vol. 22 No. 1, Juli 2019

Abdul Manan. (2008), Aneka Masalah Hukum Perdata Islam Indonesia, Jakarta: Kencana.

Erfani Aljan Abdullah. (2017), Pembaharuan Hukum Perdata Islam Praktik dan Gagasan, Yogyakarta: UII Press.

Ridwan. (2006), Kekerasan Berbasis Gender (Rekonstruksi Teologis, Yuridis, dan Sosiologis), Purwokerto: Pusat Studi Gender (PSG) Sekolah Tinggi Agama Islam Negeri (STAIN) Purwokerto.

Sulaiman Al- Kumayi. (2007), AA Gym di antara Pro- Kontra Poligami, Semaranng: PT. Pustaka Rizki Putra.

Ustad Labib MZ. (1986), Pembelaan Ummat Muhammad Terhadap Para Orientalis atau Sindiran Golongan Anti Islam Yang Mempersoalkan Nabi Muhammad SAW Beristeri Lebih Dari Satu (Rahasia Poligami Rasulullah Saw), Gresik: Bintang Pelajar.

Wila Chandrawila Supriadi. (2002), Hukum Perkawinan Indonesia dan Belanda, Bandung: CV. Mandar Maju.

\section{Artikel Jurnal:}

Dahlan Hasyim. (2007), Tinjauan Teoritis Asas Monogami Tidak Mutlak Dalam Perkawinan, Mimbar Jurnal Sosial dan Pembangunan, Universitas Islam Bandung (UNISBA), Volume XXIII No. 2 April- Juni 2007, 300-311.

\section{Peraturan Perundang- Undangan:}

Instruksi Presiden (Inpres) Nomor 1 Tahun 1991 Tentang Kompilasi Hukum Islam

Undang- Undang Nomor 1 Tahun 1974 Tentang Perkawinan

Kitab Undang- Undang Hukum Pidana (KUHP)

\section{Putusan Pengadilan:}

Putusan Majelis Hakim Pengadilan Agama Jakarta Timur Nomor: 0478/Pdt.G/2017/PAJT

\section{Website}

https://www.republika.co.id/berita/dunia-islam/islamnusantara/18/12/23/pk74ks409-poligami-dalam-perspektif-komnas-perempuan 